\title{
KINETICS AND EQUILIBRIUM MODEL OF Pb(II) AND Cd(II) ADSORPTION ONTO TETRAKIS-THIOMETHYL-C-4-METHOXYPHENYLCALIX[4]RESORCINARENE
}

\author{
Suryadi Budi Utomo ${ }^{1,2,}$, Jumina $^{2}$, Dwi Siswanta ${ }^{2}$, and Mustofa ${ }^{3}$ \\ ${ }^{1}$ Chemical Education Study Program, PMIPA FKIP, Sebelas Maret University, Surakarta \\ ${ }^{2}$ Department of Chemistry, Faculty of Mathematics and Natural Sciences, Universitas Gadjah Mada, \\ Jl. Sekip Utara, Yogyakarta 55281 \\ ${ }^{3}$ Department of Pharmacology and Toxicology, Faculty of Medicine, Universitas Gadjah Mada, Yogyakarta 55281
}

Received September 20, 2011; Accepted December 15, 2011

\begin{abstract}
The ability of tetrakis-thiomethyl-C-4-methoxyphenylcalix[4]resorcinarene for trapping $\mathrm{Pb}(\mathrm{II})$ and $\mathrm{Cd}(\mathrm{II})$ from aqueous solution at different $\mathrm{pH}$, contact times, and initial metal concentration was investigated. Concentration of metal ions before and after interaction was analyzed by Atomic Absorption Spectrophotometer (AAS). The result indicated that tetrakis-thiomethyl-C-4-methoxyphenylcalix[4]resorcinarene is a good host for metal ions, where Cd(II) sorption capacity was higher than that of $\mathrm{Pb}(\mathrm{III})$. Effect of $\mathrm{pH}$ on batch experiments for the mentioned ions indicated that the optimum $\mathrm{pH}$ for metal binding were 5 for both of lead(II) and cadmium(II). In order to investigate the mechanism of adsorption, the $1^{\text {st }}$-order, pseudo $1^{\text {st }}$-order, and pseudo $2^{\text {nd }}$-order kinetic models were used. The adsorption model of metal ions on the resorcinarene followed pseudo second order of Ho \& McKay expression. The equilibrium adsorption isotherm has been analyzed by Langmuir and Freundlich equations. Langmuir model had the higher correlation coefficient than that of Freundlich model.
\end{abstract}

Keywords: $C d(I I)$; Langmuir isotherm adsorption; $\mathrm{Pb}(I I)$; pseudo second order; tetrakis-thiomethyl-C-4-methoxy phenylcalix[4]resorcinarene

\section{ABSTRAK}

Uji kemampuan tetrakis-tiometil-C-4-metoksifenilkaliks[4]resorsinarena untuk menjebak $\mathrm{Pb}$ (II) dan Cd(II) telah dilakukan pada berbagai variasi $\mathrm{pH}$, waktu kontak dan konsentrasi larutan logam. Konsentrasi ion logam sebelum dan sesudah interaksi dianalisis dengan Spektrofotometer Serapan Atom (SSA). Hasil penelitian menunjukkan bahwa tetrakis-tiometil-C-4-metoksifenilkaliks[4]resorsinarena memiliki daya adsorpsi tinggi terhadap kedua logam tersebut dimana kapasitas penyerapan Cd(II) lebih tinggi daripada $\mathrm{Pb}(\mathrm{II})$. Pengaruh tingkat keasamaan pada percobaan batch untuk ion-ion tersebut menunjukkan bahwa adsorpsi optimum terjadi pada pH 5 baik untuk timbal(II) maupun kadmium(II). Dalam rangka mempelajari mekanisme adsorpsi yang terjadi digunakan pendekatan model kinetika reaksi orde kesatu, pseudo orde kesatu, dan pseudo orde kedua. Model adsorpsi ion logam pada resorsinarena tersebut mengikuti reaksi pseudo orde kedua Ho dan McKay. Kesetimbangan adsorpsi isoterm dianalisis dengan persamaan Langmuir dan Freundlich. Model Langmuir memiliki koefisien korelasi lebih tinggi dari model Freundlich.

Kata Kunci: Cd(II); adsorpsi isoterm Langmuir; $\mathrm{Pb}(\mathrm{II})$; orde pseudo kedua; tetrakis-tiometil-C-4metoksifenilkaliks[4]resorsinarena

\section{INTRODUCTION}

The presence of heavy metals in aquatic environment has been seriously increased during the last few decades mainly due to the industrial activities [15]. Waste streams containing heavy metals are often found in metal plating facilities, electroplating, mining operations, fertilizer, battery manufacture, dyestuffs, chemical pharmaceutical, electronic device manufactures and many others. These toxic metals are not biodegradable and their presence in streams and lakes leads to bioaccumulation in living organism, causing health problems in animals, plants, and human being [6]. Therefore, it is necessary to reduce the levels of heavy metals from aqueous solution. Many methods have been developed for these purposes include chemical precipitation, electro deposition, ion exchange, membrane separation, and adsorption.

* Corresponding author. Tel/Fax : +62-271-648939

Email address : sbukim98@yahoo.com

Suryadi Budi Utomo et al. 
Adsorption technique is a simple method, able to work at low concentrations, can be recycled and relatively inexpensive [7].

Several kinds of adsorbents have been applied for the absorption of heavy metal pollutants in the form of cations. They are zeolites [8], clay [9], soil diatomae [10], chitin [11], chitosan [12], humic acid [13], activated sludge [14], polyeugenol [15], and lignocellulose [16]. In the latest study, it has also introduced several kinds of synthetic compounds namely calixarenes and calixresorcinarenes. It has been discovered in our previous research that some calixarenes and calixresorcinarenes are significantly efficient to adsorb $\mathrm{Pb}^{2+}, \mathrm{Cd}^{2+}, \mathrm{Cr}^{3+}$, and $\mathrm{Hg}^{2+}$ metal cations either in a batch or continue adsorption processes [17-18]. The advantage of these compounds is to have some active groups which are arranged in a unique molecular geometry, like a crown or a flower vase making it possible to be used as a host molecule for cations [17-21], anions [22-23] and organic neutral molecules [24-25]. Unlike natural adsorbents above, the structure and shape of calix[4]resorcinarene molecules can be clearly elucidated so that the adsorption mechanism can also be understood more easily.

In this publication, we describe the profile of kinetics and equilibrium adsorption of $\mathrm{Pb}$ (II) and $\mathrm{Cd}(\mathrm{II})$ onto tetrakis-thiomethyl-C-4-methoxyphenylcalix[4] resorcinarene in a batch reactor system. The influence of experimental parameter such as $\mathrm{pH}$, contact times, and initial metal concentration were studied. Kinetic adsorption behavior was evaluated through some kinetic models i.e. first order of Santosa et al. [11], pseudo-first order of Lagergren [26], and pseudo-second order of Ho \& McKay [27]. The equilibrium adsorption isotherm was determined according to Langmuir and Freundlich adsorption isotherm models. Tetrakis-thiomethyl-C-4methoxyphenylcalix[4]resorcinarene has active sites in the form of hydroxyl (-OH) and thiol (-SH) groups, arranged in specific conformation, that expected to be a high-performance effective host macrocyclic molecule against the desired guests of $\mathrm{Pb}(\mathrm{II})$ and $\mathrm{Cd}(\mathrm{II})$.

\section{EXPERIMENTAL SECTION}

\section{Materials}

p-methoxybenzaldehyde, resorcinol, TLC, dichloromethane, ethyl acetic, methanol, potassium permanganate, sulphuric acid, acetone, ethanol, fuming hydrochloric acid, dimethylformamide, paraformal dehyde, zinc chloride, thiourea, sodium hydroxide, nitric acid, $\mathrm{Pb}(\mathrm{NO})_{3}$, and $\mathrm{Cd}(\mathrm{NO})_{3}$. All reagents in analytical grade were obtained from E Merck Co Inc. (Germany) and used without further purification

\section{Instrumentation}

In general, the melting points of compounds were determined on melting point electro thermal 9100 and are not corrected. Preparative TLC was carried out on $20 \times 20 \times 0.1 \mathrm{~cm}$ plates using Merck silica gel 7730 $60 \mathrm{GF}_{254}$. Compounds were detected by short and long wavelength ultraviolet light. FTIR spectra were taken on Shimadzu FTIR-Prestige-21. NMR spectra were recorded in the designated solvents on a JEOL 500 $\mathrm{MHz}$ or a Bruker AC300F $300 \mathrm{MHz}$ spectrometer. Chemical shifts are reported as $\delta$ values in ppm relative to TMS $(\delta \quad 0.0)$ as an internal standard. Concentration of each cation was determined using an Atomic Absorption Spectrophotometer (AAS, AA-6650F Shimadzu).

\section{Procedure}

\section{Synthesis of tetrakis-thiomethyl-C-4-methoxy phenylcalix[4]resorcinarene \\ Tetrakis-thiomethyl-C-4-methoxyphenylcalix[4]}

resorcinarene was synthesized from $p$ methoxybenzaldehyde according to the Jumina et al. [17] and Utomo et al. [28] procedures. The product was filtered, washed twice with water and dried in vacuum to give an orange-brown powder in $78.85 \%$; $\mathrm{mp} 300{ }^{\circ} \mathrm{C}$; FTIR (KBr) $v\left(\mathrm{~cm}^{-1}\right): 3371$ (OH group), 3063 $\left(\mathrm{C}_{\mathrm{sp} 2}-\mathrm{H}\right), \quad 1604$ and $1512(\mathrm{C}=\mathrm{C}$ aromatic $), 2931$ $\left(\mathrm{C}_{\mathrm{sp} 3}-\mathrm{H}\right), 2568(-\mathrm{SH}), 1466\left(-\mathrm{CH}_{2}-\right), 1442\left(\mathrm{Ar}_{2} \mathrm{CHAr}\right)$, $1381\left(-\mathrm{CH}_{3}\right) ;{ }^{1} \mathrm{H}-\mathrm{NMR}\left(300 \mathrm{MHz}\right.$, DMSO-d $d_{6} \delta(\mathrm{ppm})$ : $7.95(8 \mathrm{H}, s, \mathrm{OH}), 6.54-6.59(20 \mathrm{H}$, broad $d, \mathrm{ArH}), 5.64$ $\left(4 \mathrm{H}, s, \mathrm{Ar}_{2} \mathrm{CHAr}\right), 3.69\left(12 \mathrm{H}, s, \mathrm{OCH}_{3}\right), 2.73$ and 2.88 $\left(8 \mathrm{H}\right.$, double $\left.s, \quad \mathrm{ArCH}_{2} \mathrm{Cl}\right), 1.28(-\mathrm{SH}) ;{ }^{13} \mathrm{C}-\mathrm{NMR}$ (75 MHz, DMSO- $d_{6}$ ) $\delta$ (ppm): 157.80 (-C-OMe), 152.64 $(-\mathrm{C}-\mathrm{OH}), 134.00,130.28,129.85,124.44,123.53$, 113.25 (Ar), $55.04\left(\mathrm{OCH}_{3}\right)$, and $31.17\left(\mathrm{Ar}_{2} \mathrm{CHAr}\right), 8.34$ $\left(\mathrm{Ar}-\mathrm{CH}_{2}-\mathrm{SH}\right)$. The product was obtained in the shape of crown conformation [28].

\section{Effect of $\mathrm{pH}$}

Metal solutions were prepared by diluting $1000 \mathrm{mg} / \mathrm{L} \mathrm{Pb}\left(\mathrm{NO}_{3}\right)_{2}$ and $\mathrm{Cd}\left(\mathrm{NO}_{3}\right)_{3}$ standard solution in aqueous nitric acid to desired concentrations. $\mathrm{pH}$ adjustment was carried out by adding slowly $\mathrm{NaOH}$ and/ or $\mathrm{HNO}_{3}$ solution followed by stirring until a certain acidity. A series of flasks containing $100 \mathrm{~mL}$ of $8 \mathrm{ppm}$ metal solution with $\mathrm{pH}$ of $1,2,3,4,5,6$, and 7 were prepared. Into each of the series solution was added $0.06 \mathrm{~g}$ of tetrakis-thiomethyl-C-4-methoxyphenylcalix[4] resorcinarene. The mixtures were then equilibrated for $3 \mathrm{~h}$ at $25^{\circ} \mathrm{C}$ and the solid material of resorcinarene was filtered. The residual concentration of metal ion was determined spectrophotometically by using Atomic Absorption Spectrometry (AAS) apparatus. 


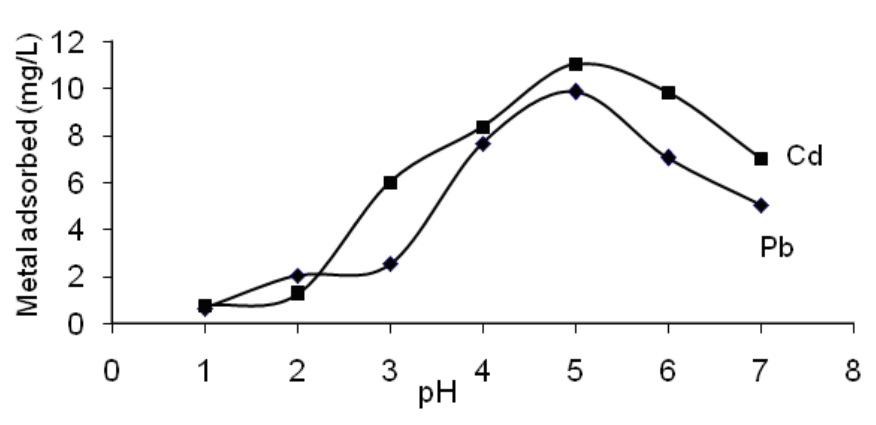

Fig 1. Effect of $\mathrm{pH}$ on metal ions binding

\section{Effect of contact time}

The effect of time on adsorption was investigated in the agitation time range of $5-405 \mathrm{~min}$. A $0.06 \mathrm{~g}$ of tetrakis-thiomethyl-C-4-methoxyphenylcalix[4]resorcinare ne was added into $100 \mathrm{~mL}$ of sample solution containing metal ion with the concentration of $20 \mathrm{ppm}$. The acidity of sample solution adjusted to optimum $\mathrm{pH}$ as previous experimental results. The contents of the flask were agitated at $25{ }^{\circ} \mathrm{C}$. Two point five milliliters of the solution was taken at different time intervals of $5,15,45,135$, and $405 \mathrm{~min}$ followed by dilution with the addition of distilled water $(2.5 \mathrm{~mL}, \mathrm{pH} 2)$. The residual concentration of metal ion in the blank and samples solution were determined using Atomic Absorption Spectrometry (AAS). Blank solution serves as a controller of the occurrence of metal ions, which were precipitated after treatment.

\section{Effect of initial concentration}

An accurate weight $(0.06 \mathrm{~g})$ of tetrakis-thiomethylC-4-methoxyphenylcalix[4]resorcinarene was mixed and stirred with $100 \mathrm{~mL}$ solutions of lead and cadmium at optimum $\mathrm{pH}$. The investigated initial concentrations were $10,20,30,40$, and $50 \mathrm{mg} / \mathrm{L}$. The blank experiments were simultaneously carried out without the adsorbent. After shaking in a thermostatic system $\left(25^{\circ} \mathrm{C}\right)$ for the time according to the optimum condition of metal ion binding, the solid phase was separated by filtration. The concentration of metal ions was calculated by AAS through dilution with distilled water.

\section{RESULT AND DISCUSSION}

\section{pH Profile Studies for Metal lons Binding}

Determination of optimum $\mathrm{pH}$ on adsorption is an important study in evaluating the interaction between metal ions with active sites on tetrakis-thiomethyl-C-4methoxyphenylcalix[4]resorcinarene. In the process of adsorption, the $\mathrm{pH}$ of the solution may affect 1) the adsorbent surface charge [18], 2) the distribution of metal species [29], and 3) the level of dissociation of

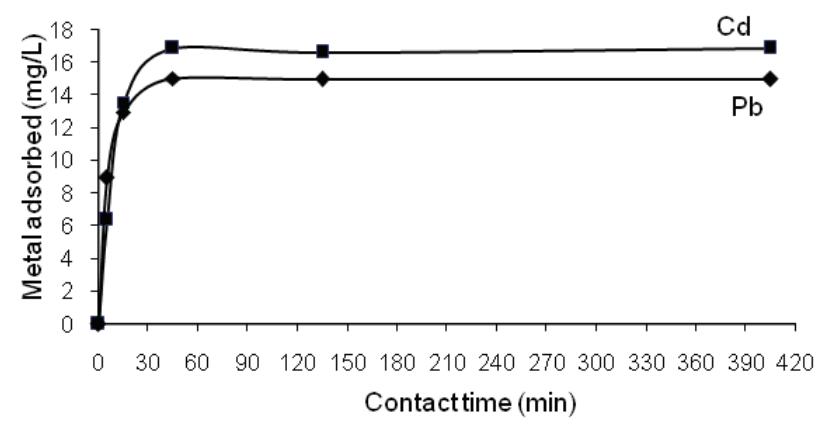

Fig 2. Effect of contact time on adsorption metal ions onto the resorcinarene

functional groups on the active sites of adsorbent [30]. Effect of $\mathrm{pH}$ on the adsorption of metal ions in this research was studied at $\mathrm{pH}$ in the range of 1-7. The reason for selecting this range of acidity is based on the consideration that at $\mathrm{pH}$ below 7 , both of lead and cadmium are dominantly exist in the desired form of $\mathrm{Pb}^{2+}$ and $\mathrm{Cd}^{2+}$. While in the neutral and base solution, there will be other lead and cadmium species of $\mathrm{PbOH}^{+}, \mathrm{PbCO}_{3}{ }^{\circ}, \mathrm{PbHCO}_{3}{ }^{+}$, and $\left[\mathrm{Cd}(\mathrm{OH})_{2} \cdot\left(\mathrm{H}_{2} \mathrm{O}\right)_{3}\right]_{(\mathrm{s})}$ that may interfere on the interaction of $\mathrm{Pb}^{2+}$ and $\mathrm{Cd}^{2+}$ ions with tetrakis-thiomethyl-C-4-methoxyphenylcalix[4] resorcinarene.

The curve of relationship between the amount of $\mathrm{Pb}(\mathrm{II})$ and $\mathrm{Cd}(\mathrm{II})$ adsorbed in various $\mathrm{pH}$ is shown in Fig. 1. It was found that metal ions adsorption capacity of tetrakis-thiomethyl-C-4-methoxyphenylcalix[4]resorcin arene increased from $\mathrm{pH} 1.0$ to 5.0 , and decreased from $\mathrm{pH} 6.0$ to 7.0. It can be concluded that the $\mathrm{pH}$ around 5 is the optimum $\mathrm{pH}$ of $\mathrm{Pb}(\mathrm{II})$ and $\mathrm{Cd}(\mathrm{II})$ adsorption onto the resorcinarene. This results is in accordance with the reality in which in this range of medium acidity, lead and cadmium predominantly exist in the form of cation species and the amount of metal ions of $\mathrm{Pb}^{2+}$ and $\mathrm{Cd}^{2+}$ in the sample solution were not much precipitated.

The concentration of $\mathrm{Pb}(\mathrm{II})$ and $\mathrm{Cd}(\mathrm{II})$ adsorbed at $\mathrm{pH}$ lower than 3 are much smaller than that of $\mathrm{pH} 4,5$, and 6 . In this medium, $\mathrm{pH}<3$, hydroxyl $(-\mathrm{OH})$ and thiol (-SH) groups on tetrakis-thiomethyl-C-4-methoxyphenyl calix[4]resorcinarene will be protonated so that these active sides tend to positively charged. Thus, in highly acidic conditions most likely will happen electrostatic repulsion interaction between the adsorbent and the adsorbate due to the same positive character. In other words, there was adsorption competition between proton with metal cations of lead and cadmium that causes the least amount of metal ions adsorbed by the resorcinarene. At $\mathrm{pH}$ greater than 3 , the number of protons in solution decreased with increasing $\mathrm{pH}$ so that adsorption competition between $\mathrm{H}^{+}$with $\mathrm{Pb}^{2+}$ and $\mathrm{Cd}^{2+}$ further reduced, resulting in escalating adsorption 
Table 1. Kinetic modeling and its adsorption kinetic parameters

\begin{tabular}{|c|c|c|c|}
\hline Kinetic models & Equation & Rate constant, $k \times 10^{-3}$ & Correlation coefficient, $\mathrm{R}^{2}$ \\
\hline $\begin{array}{l}1^{\text {st }} \text {-order of } \\
\text { Santosa }\end{array}$ & $\ln \left(\frac{C_{0}}{C_{a}}\right)$ & $\begin{array}{l}\mathrm{Pb}(\mathrm{II}): 3.39\left(\mathrm{~min}^{-1}\right) \\
\mathrm{Cd}(\mathrm{II}): 1.94\left(\mathrm{~min}^{-1}\right)\end{array}$ & $\begin{array}{l}\mathrm{Pb}(\mathrm{II}): 0.554 \\
\mathrm{Cd}(\mathrm{II}): 0.353\end{array}$ \\
\hline & $\frac{C_{a}}{C_{a}}=k_{1} \frac{i}{C_{a}}+K$ & & \\
\hline $\begin{array}{l}\text { Pseudo } 1^{\text {st }} \text {-order } \\
\text { of Lagergren }\end{array}$ & $\log \left(q_{e}-q_{t}\right)=\log q_{e}-k_{1} t$ & $\begin{array}{l}\mathrm{Pb}(\mathrm{II}): 6.37\left(\mathrm{mg} \cdot \mathrm{g}^{-1} \cdot \mathrm{min}^{-1}\right) \\
\mathrm{Cd}(\mathrm{II}): 9.79\left(\mathrm{mg} \cdot \mathrm{g}^{-1} \cdot \mathrm{min}^{-1}\right)\end{array}$ & $\begin{array}{l}\mathrm{Pb}(\mathrm{II}): 0.799 \\
\mathrm{Cd}(\mathrm{II}): 0.167\end{array}$ \\
\hline $\begin{array}{l}\text { Pseudo } 2^{\text {nd }}- \\
\text { order of Ho } \& \\
\text { Mc Kay }\end{array}$ & $\frac{t}{q_{t}}=\frac{1}{k_{2} q_{e}{ }^{2}}+\frac{t}{q_{e}}$ & $\begin{array}{l}\mathrm{Pb}(\mathrm{II}): 21.09\left(\mathrm{~g} \cdot \mathrm{mg}^{-1} \cdot \mathrm{min}^{-1}\right) \\
\left.\mathrm{Cd}(\mathrm{II}): 8.20 \mathrm{~g} \cdot \mathrm{mg}^{-1} \cdot \mathrm{min}^{-1}\right)\end{array}$ & $\begin{array}{l}\mathrm{Pb}(\mathrm{II}): 0.999 \\
\mathrm{Cd}(\mathrm{II}): 0.999\end{array}$ \\
\hline
\end{tabular}

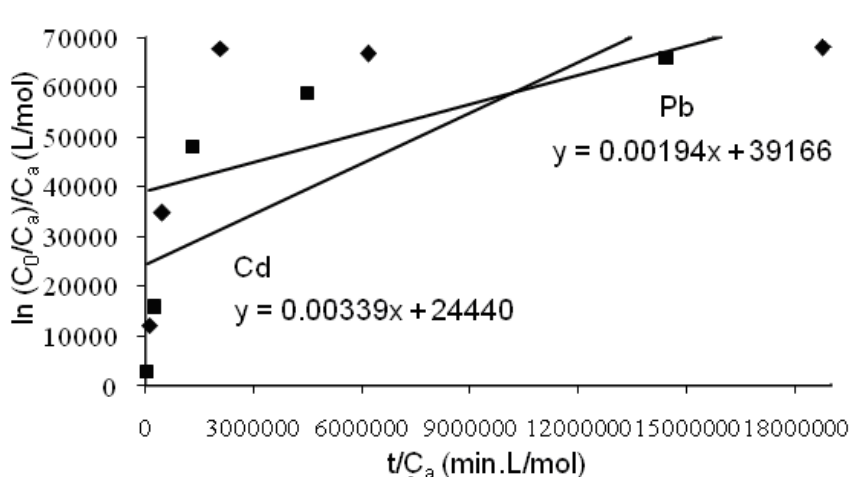

Fig 3. First order kinetic for metals adsorption on the resorcinarene

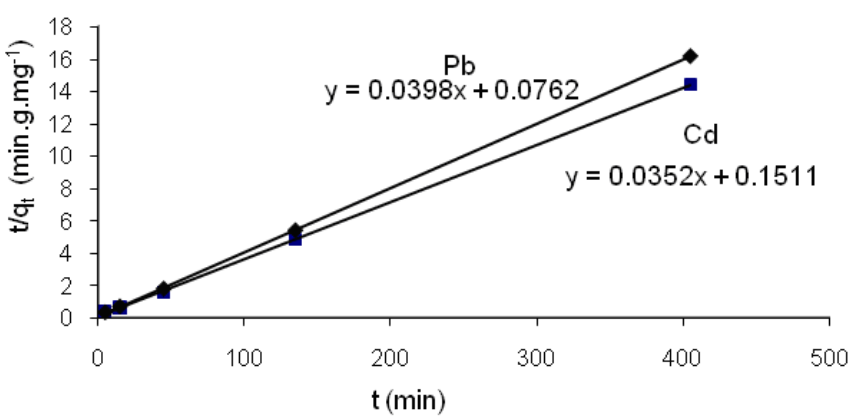

Fig 5. Pseudo second order kinetic for metals adsorption on the resorcinarene

of metal ions by tetrakis-thiomethyl-C-4-methoxyphenyl calix[4]resorcinarene.

\section{Adsorption Kinetics}

Effect of contact time on adsorption behavior of $\mathrm{Pb}^{2+}$ and $\mathrm{Cd}^{2+}$ metal ions onto the host molecule of resorcinarene are presented in Fig. 2. It was found that the metal ions adsorption capacity increased with increasing contact time. Above $50 \%$ of metal ions adsorption occurred in the first 15 to $45 \mathrm{~min}$, and thereafter the rate of adsorption of $\mathrm{Pb}^{2+}$ and $\mathrm{Cd}^{2+}$ onto the adsorbent were found to be constant. At that time, equilibrium of the adsorption had reached.

The time-dependent experimental adsorption data (Fig. 2) are used for kinetic modeling. In order to analyze the adsorption kinetics of $\mathrm{Pb}(\mathrm{II})$ and $\mathrm{Cd}(\mathrm{II})$ onto tetrakis-

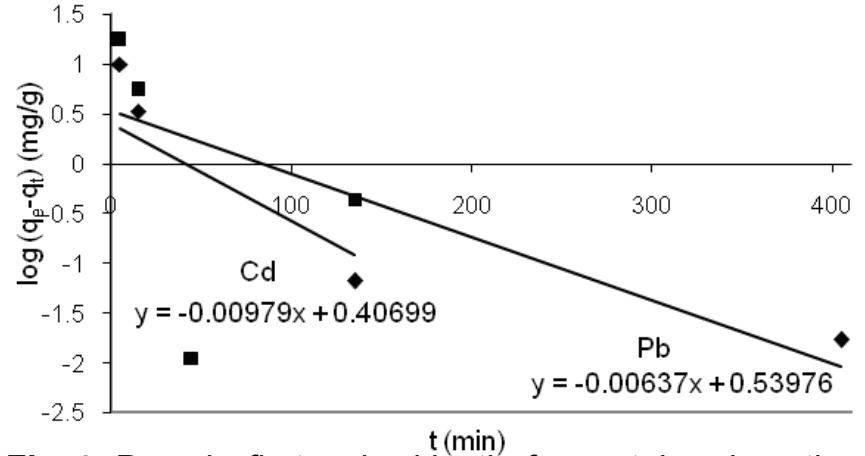

Fig 4. Pseudo first order kinetic for metals adsorption on the resorcinarene

thiomethyl-C-4-methoxyphenylcalix[4]resorcinarene, the first order metal adsorption of Santosa et al. [11], pseudo-first order of Lagergren [26], and pseudosecond order of Ho \& McKay [27] models, were applied to the data.

Santosa et al. [11] has made a kinetic equation model of a single metal ion adsorption on the adsorbent with an overview of the concentration of adsorbate in the liquid phase. This kinetic formulation is based on the assumption that the adsorption process is the first order metal adsorption reaching equilibrium. Mathematical equation for a single ion condition can be indicated by equation (1).

$\frac{\ln \left(\frac{C_{0}}{C_{a}}\right)}{C_{a}}=k_{1} \frac{t}{C_{a}}+K$

where $\mathrm{C}_{0}$ is the initial metal concentration ( $\left.\mathrm{mol} / \mathrm{L}\right), \mathrm{C}_{a}$ is the concentration of metal ions in solution at time $t$ $(\mathrm{mol} / \mathrm{L}), \mathrm{t}$ is the adsorption time $(\mathrm{min}), \mathrm{k}_{1}$ is the firstorder rate adsorption constant $\left(\mathrm{min}^{-1}\right)$, and $\mathrm{K}$ is adsorption-desorption equilibrium constant $(\mathrm{mol} / \mathrm{L})^{-1}$. The resulted relationship between $\ln \left(\mathrm{C}_{0} / \mathrm{C}_{\mathrm{a}}\right) / \mathrm{C}_{\mathrm{a}}$ versus $\mathrm{t} / \mathrm{C}_{\mathrm{a}}$ as shown in Fig. 3 .

The approach to the second kinetics model is reviewed based on the concentration of adsorbate in solid phase (the adsorbent). In order to distinguish kinetics equation based on concentration of solution and adsorption capacity of solid, Lagergren's first order and Ho's second order rate equations have been called 
Table 2. Data on Langmuir and Freundlich adsorption isotherm for $\mathrm{Pb}(\mathrm{II})$

\begin{tabular}{rcrrrrrrr}
\hline No & $\begin{array}{c}\mathrm{C}_{0} \\
(\mathrm{mg} / \mathrm{L})\end{array}$ & $\begin{array}{c}\mathrm{C}_{\mathrm{e}} \\
(\mathrm{mg} / \mathrm{L})\end{array}$ & $\begin{array}{c}\mathrm{C}_{\mathrm{e}}(\mathrm{mol} / \mathrm{L}) \\
\times 10^{-5}\end{array}$ & $\begin{array}{c}\mathrm{q} \mathrm{q}_{\mathrm{e}} \\
(\mathrm{mg} / \mathrm{L})\end{array}$ & $\begin{array}{c}\mathrm{q}_{\mathrm{e}}(\mathrm{mol} / \mathrm{L}) \\
\times 10^{-5}\end{array}$ & $\mathrm{C}_{\mathrm{e}} / \mathrm{q}_{\mathrm{e}}$ & $\begin{array}{c}\text { log } \mathrm{Ce} \\
(\mathrm{mol} / \mathrm{L})\end{array}$ & $\begin{array}{c}\text { log } \mathrm{qe} \\
(\mathrm{mol} / \mathrm{L})\end{array}$ \\
\hline 1 & 44.945 & 22.177 & 10.706 & 22.768 & 10.910 & 0.974 & -3.970 & 1.357 \\
2 & 39.859 & 19.689 & 9.505 & 20.170 & 9.737 & 0.976 & -4.022 & 1.305 \\
3 & 28.906 & 10.802 & 5.214 & 18.104 & 8.739 & 0.597 & -4.283 & 1.258 \\
4 & 19.482 & 4.484 & 2.165 & 14.998 & 7.241 & 0.299 & -4.665 & 1.176 \\
5 & 11.755 & 1.593 & 0.769 & 10.162 & 4.906 & 0.157 & -5.114 & 1.007 \\
\hline
\end{tabular}

Table 3. Data on Langmuir and Freundlich adsorption isotherm for $\mathrm{Cd}(\mathrm{II})$

\begin{tabular}{lcrrrrrrr}
\hline No & $\begin{array}{c}\mathrm{C}_{0} \\
(\mathrm{mg} / \mathrm{L})\end{array}$ & $\begin{array}{c}\mathrm{C} \mathrm{m} / \mathrm{L}) \\
\mathrm{C}\end{array}$ & $\begin{array}{r}\mathrm{C}_{\mathrm{e}}(\mathrm{mol} / \mathrm{L}) \\
\times 10^{-5}\end{array}$ & $\begin{array}{c}\mathrm{q}_{\mathrm{e}} \\
(\mathrm{mg} / \mathrm{L})\end{array}$ & $\begin{array}{c}\mathrm{q}_{\mathrm{e}}(\mathrm{mol} / \mathrm{L}) \\
\times 10^{-5}\end{array}$ & $\mathrm{C}_{\mathrm{e}} / \mathrm{q}_{\mathrm{e}}$ & $\begin{array}{c}\text { log } \mathrm{Ce} \\
(\mathrm{mol} / \mathrm{L})\end{array}$ & $\begin{array}{c}\text { log } \mathrm{qe} \\
(\mathrm{mol} / \mathrm{L})\end{array}$ \\
\hline 1 & 49.867 & 19.915 & 17.718 & 29.952 & 26.648 & 0.665 & -3.752 & 1.476 \\
2 & 40.208 & 14.584 & 12.975 & 25.624 & 22.797 & 0.569 & -3.887 & 1.409 \\
3 & 29.904 & 7.509 & 6.681 & 22.395 & 19.924 & 0.335 & -4.175 & 1.350 \\
4 & 20.011 & 3.151 & 2.803 & 16.860 & 15.000 & 0.187 & -4.552 & 1.227 \\
5 & 10.472 & 1.544 & 1.373 & 8.928 & 7.944 & 0.173 & -4.862 & 0.951 \\
\hline
\end{tabular}

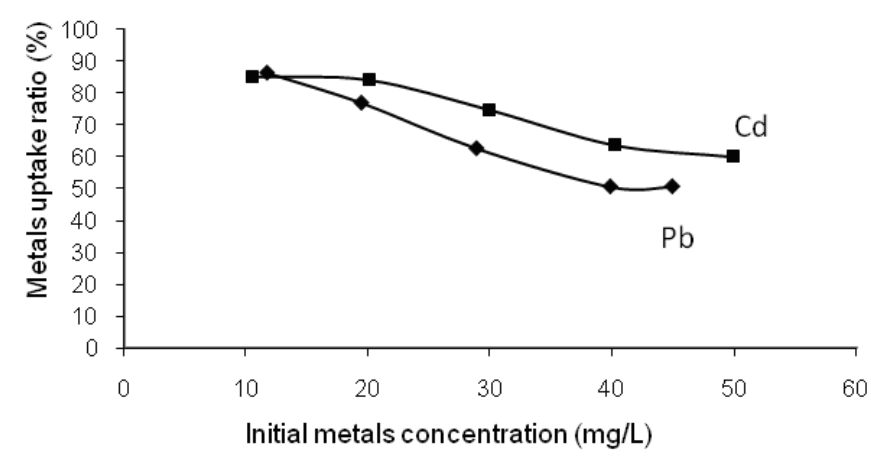

Fig 6. Effect of initial concentration on metals uptake ratio

pseudo-first order and pseudo-second order respectively. The pseudo $1^{\text {st }}$-order equation is generally expressed as follow:

$\log \left(q_{e}-q_{t}\right)=\log q_{e}-k_{1} t$

and the pseudo $2^{\text {nd }}$-order kinetic model is expressed as:

$\frac{t}{q_{t}}=\frac{1}{k_{2} q_{e}{ }^{2}}+\frac{t}{q_{e}}$

where $q_{e}$ and $q_{t}\left(m g . g^{-1}\right)$ are the adsorption capacities at equilibrium and at time $t$, while $k_{1}$ and $k_{2}$ are the rate constant of pseudo-first order and pseudo-second order adsorption respectively. $\mathrm{k}_{1}$ was determined from the slope of the plot of log $\left(q_{e}-q_{t}\right)$ versus $t$ (Fig. 4) and $k_{2}$ was obtained from the plot of $t / q_{t}$ versus $t$ (Fig. 5). The values of $\mathrm{k}_{1}$ and $\mathrm{k}_{2}$ were calculated and recorded in Table 1.

Based on Fig. 5 shows that the resulting curve has the highest level of linearity when compared with previous determination of first order metal adsorption reaching equilibrium (Fig. 3) and pseudo-first order adsorption (Fig. 4). Thus, it can be concluded that the kinetic pattern of $\mathrm{Pb}(\mathrm{II})$ and $\mathrm{Cd}(\mathrm{II})$ adsorption onto tetrakis-thiomethyl-C-4-methoxyphenylcalix[4]resorcinare ne followed pseudo-second order kinetic model.

If the adsorption rate of $\mathrm{Pb}(\mathrm{II})$ and $\mathrm{Cd}(\mathrm{II})$ were compared based on the value of rate constant of the pseudo second order reaction of Ho \& McKay, it should be pointed out that the adsorption reactions of $\mathrm{Pb}(\mathrm{II})$ faster than the adsorption reaction of $\mathrm{Cd}(\mathrm{II})$ onto tetrakis-thiomethyl-C-4-methoxyphenylcalix[4]resorcina rene. This sequential adsorption rate constant value is consistent with previous research results for both reaction kinetics of single metal ions adsorption of $\mathrm{Pb}(\mathrm{II}), \mathrm{Cd}(\mathrm{II})$, and $\mathrm{Cr}(\mathrm{III})$ onto binding cross-protected products of humic acid/chitosan [31] and the reaction kinetics of single ion adsorption of $\mathrm{Pb}$ (II) and $\mathrm{Cr}$ (III) in polymer compound of polypropylcalix[4]arene [18]. However, the adsorption rate of $\mathrm{Pb}$ (II) onto tetrakisthiomethyl-C-4-methoxyphenyl calix[4]resorcinarene was lower than that of $\mathrm{Pb}$ (II) on polypropylcalix[4] arene. It caused by the active sites of hydroxyl group $(-\mathrm{OH})$ on polypropylcalix[4]arene more dispersed along the polymer chain. Rate constants of adsorption of $\mathrm{Pb}$ (II) onto polypropylcalix[4]arene was $6.81 \mathrm{x}$ $10^{-1} \mathrm{~g} \cdot \mathrm{mg}^{-1} \cdot \mathrm{min}^{-1}$.

\section{Adsorption Isotherms}

The adsorption behavior of $\mathrm{Pb}(\mathrm{II})$ and $\mathrm{Cd}(\mathrm{II})$ onto the resorcinarene in various of initial metals concentrations are presented in Fig. 6. The ratio of metal uptake at low concentrations showed a higher percentage than the use of high initial concentration of the metals. On the use of highly initial metal concentration, it should be more crowded metal cations that diffused onto resorcinarene, thus the percentage of adsorption getting down on the same weight of adsorbent. However, the amount of adsorbate $(\mathrm{mg} / \mathrm{g}$ ) on solid phase adsorbent with higher initial metal concentrations still showed a greater capacity when compared with the use of initial low metal concentrations (Table 2 and 3). Thus, in this case, in the higher metal ions concentration will more and more ions that interact with the site active of the resorcinarene 


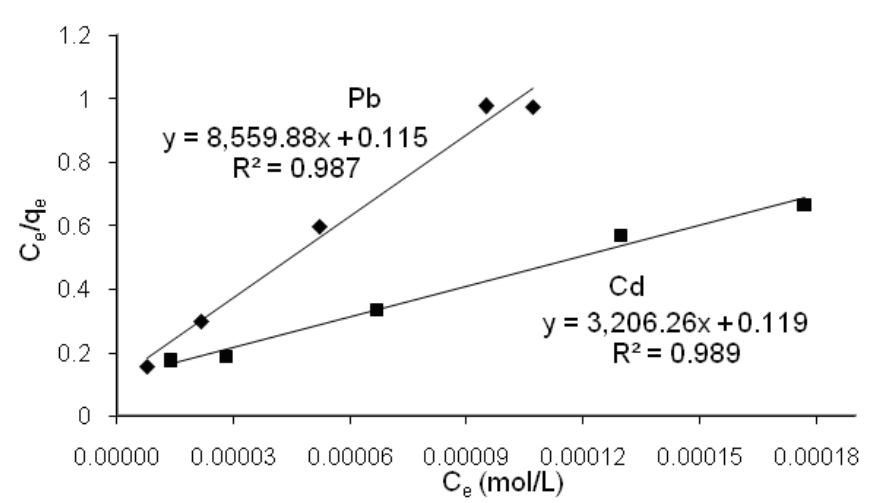

Fig 7. Langmuir isotherm for metals adsorption on the resorcinarene

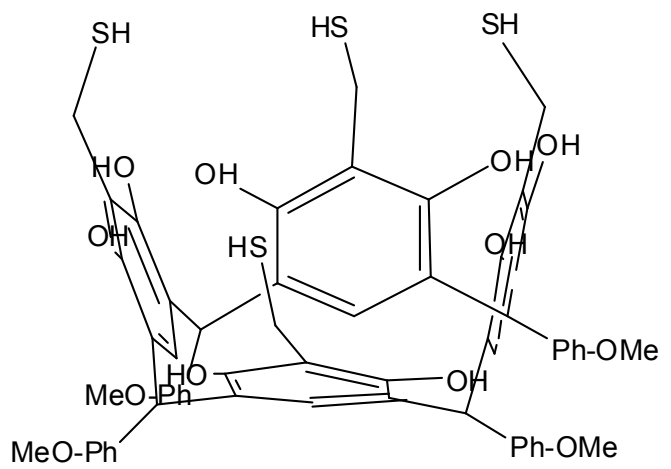

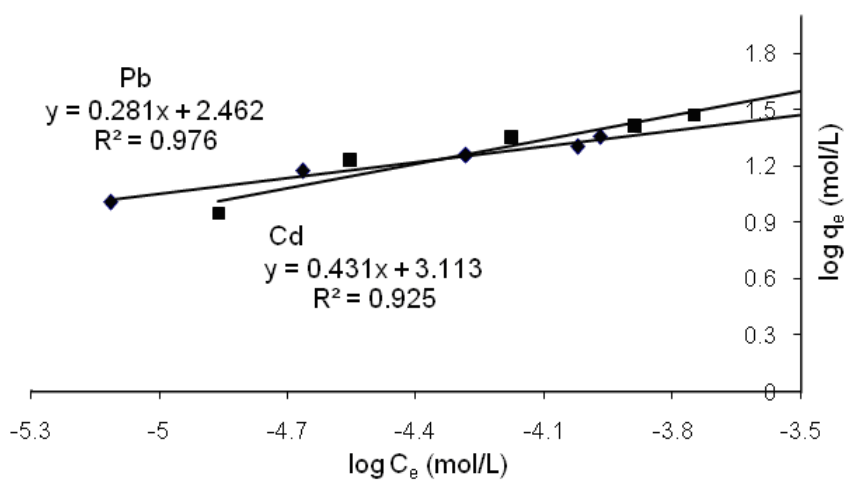

Fig 8. Freundlich isotherm for metals adsorption on the resorcinarene

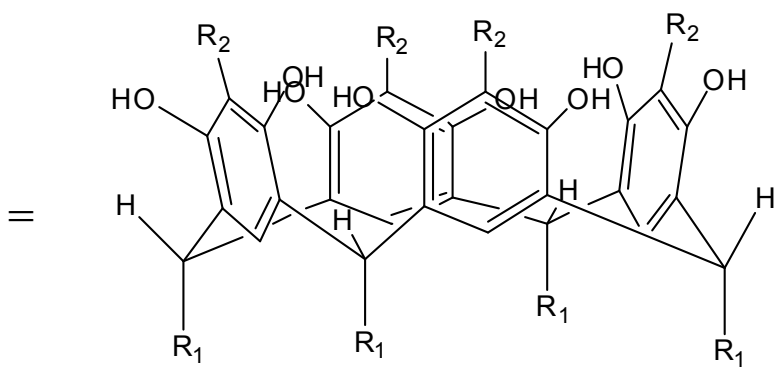

$\mathrm{R}_{1}=\mathrm{PhOMe} ; \mathrm{R}_{2}=\mathrm{CH}_{2} \mathrm{SH}$

Fig 9. Tetrakis-thiomethyl-C-4-methoxyphenylcalix[4]resorcinarene conformer

Table 4. Langmuir isotherm parameters

\begin{tabular}{lcrrrr}
\hline Metal & $\begin{array}{c}\text { Slope } \\
\left(1 / X_{m}\right)\end{array}$ & $\begin{array}{c}X_{m} \\
(\mathrm{mg} / \mathrm{g})\end{array}$ & $\begin{array}{c}\text { intercept } \\
1 /\left(X_{m} . K\right)\end{array}$ & $K(\mathrm{~L} / \mathrm{mol})$ & $\begin{array}{c}\Delta G^{0} \mathrm{Ads} \\
(\mathrm{kJ} / \mathrm{mol})\end{array}$ \\
\hline $\mathrm{Pb}(\mathrm{II})$ & 8559.88 & 40.33 & 0.115 & 77034.78 & -27.877 \\
$\mathrm{Cd}(\mathrm{II})$ & 3206.26 & 58.43 & 0.119 & 26941.18 & -25.274 \\
\hline
\end{tabular}

until reach its maximum adsorption capacity in which all of the active sites of the adsorbent are filled by metal ions.

The adsorption isotherm indicates how the adsorption molecules distribute between the liquid phase and solid phase when the adsorption process reaches an equilibrium state. The analysis of the isotherm data by fitting to the different isotherm types is important step to find the suitable model that can be used for design purpose. The adsorption capacity of this system was investigated by the two adsorption isotherm as Langmuir and Freundlich isotherm. Langmuir equation is defined by:

$1 / q_{e}=1 /\left(X_{m} \cdot K \cdot C_{e}\right)+1 / X_{m}$

While the empirical Freundlich equation based on sorption on a heterogeneous surface is given by Eq. 5 .

$\log q_{e}=\log K+1 / \mathrm{n} \log C_{e}$

where $\mathrm{q}_{\mathrm{e}}$ is the amount of the adsorbate adsorbed per unit mass of adsorbent $\left(\mathrm{mg} \cdot \mathrm{g}^{-1}\right), X_{m}$ is the maximum adsorption capacity $\left(\mathrm{mg}^{-1} \mathrm{~g}^{-1}\right), \mathrm{C}_{\mathrm{e}}$ is the equilibrium concentration of the adsorbate $\left(\mathrm{mg} \cdot \mathrm{L}^{-1}\right)$, and $\mathrm{K}$ is the equilibrium constant (L.mol $\left.{ }^{-1}\right)$.

Based on data in Table 2 and 3 , using the equation of Langmuir adsorption isotherms, plot of $\mathrm{C}_{\mathrm{e}} / \mathrm{q}_{\mathrm{e}}$ versus $\mathrm{C}_{\mathrm{e}}$ was obtained a graph with the equation of a straight line as shown in Fig. 7. Meanwhile, according to Freundlich model, by plotting log $\mathrm{q}_{\mathrm{e}}$ versus $\log \mathrm{C}_{\mathrm{e}}$ a curve in Fig. 8 was yielded. Based on the Langmuir and Freundlich isotherm curves, the linearity of Langmuir graph is higher than that of Freundlich graph for both of $\mathrm{Pb}$ (II) and $\mathrm{Cd}(\mathrm{II})$. Thus, the adsorption process of $\mathrm{Pb}(\mathrm{II})$ and $\mathrm{Cd}(\mathrm{II})$ onto resorcinarene adsorbent more appropriate and likely to follow the model of Langmuir adsorption isotherm. This means that the adsorption process occurred on monolayer, the adsorption pattern followed the Langmuir adsorption isotherm which has the assumption that maximum adsorption occurs when all active sites of adsorbent were fully filled by the adsorbate to form a monolayer. Adsorption isotherm showed that the increase in initial concentration followed by an increasing amount of adsorbed substance in order to reach an equilibrium state.

When viewed from the equation of Langmuir isotherm adsorption model, $1 / q_{e}=1 /\left(X_{m} \cdot K \cdot C_{e}\right)+1 / X_{m}$, then the model equation shows and leads to the second order kinetic model equations. This result is in 
accordance with the reality on the previous discussion on modeling approaches in which the adsorption pattern was much affected by the contact time, the adsorption kinetic are fitted well with pseudo-second order reaction. Thus, from these data confirmation, the adsorption behavior of $\mathrm{Pb}(\mathrm{II})$ and $\mathrm{Cd}(\mathrm{II})$ onto tetrakis-thiomethyl-C4-methoxyphenylcalix[4]resorcinarene by using various review of kinetic and equilibrium models obtained the conclusion that are consistent and not contradict each other.

The maximum adsorption capacity and adsorption energy both of the metal cations onto the resorcinarene can be determined on the basis of Langmuir equation. The equilibrium constant $(\mathrm{K})$ and maximum adsorption capacity can be calculated from the intercept and slope of the linier equation (Fig. 7), then, several adsorption parameters are presented in Table 4 . In comparation with other several calixarene compounds, the adsorption capacity of tetrakis-thiomethyl-C-4-methoxyphenyl calix[4]resorcinarene was much greater. For example, Cmethylcalix[4]resorcinarene [32], C-4-methoxyphenyl calix[4]arene [17], and polypropylcalix[4]arene [18] reported only able to absorb $\mathrm{Pb}^{2+}$ ions in maximum amount of $0.6,3.9$, and $16.31 \mathrm{mg} / \mathrm{g}$ adsorbent, respectively. Meanwhile, the highest adsorption capacity of $p$-bromopropylcalix[6]arene was only $0.45 \mathrm{mg} / \mathrm{g}$ for $\mathrm{Pb}^{2+}$ and $0.19 \mathrm{mg} / \mathrm{g}$ for $\mathrm{Cd}^{2+}[33]$.

The capability of tetrakis-thiomethyl-C-4-methoxy phenylcalix[4]resorcinarene on adsorption of $\mathrm{Cd}(\mathrm{II})$ was relatively higher than that of $\mathrm{Pb}(\mathrm{II})$. It most probably caused by the existence of the active sites of thiol groups (-SH). According to our previous publication [28], this resorcinarene tend to exist in the crown or cone conformation in which fourth thiol groups are arranged at outer sites of the resorcinarene (Fig. 9). Thus, these groups dominantly play the important rule on binding interaction with the guest of the metal cations. Furthermore, thiol group is classified into soft base that also tend to prefer to interact with soft acids to, in this case is $\mathrm{Cd}(\mathrm{II})$, whereas $\mathrm{Pb}(\mathrm{II})$ is a moderate-hard metal.

\section{CONCLUSION}

Tetrakis-thiomethyl-C-4-methoxyphenylcalix[4] resor cinarene is a good host for $\mathrm{Pb}(\mathrm{II})$ and $\mathrm{Cd}(\mathrm{II})$. The resorcinarene was found to be able to trap $\mathrm{Pb}$ (II) and $\mathrm{Cd}(\mathrm{II})$ in the magnitude of $86.45 \%$ and $82.19 \%$ at initial metal concentration of $10 \mathrm{ppm}$. Effect of $\mathrm{pH}$ on batch experiments indicated that the optimum $\mathrm{pH}$ for metal binding were 5 for both of lead(II) and cadmium(II). The adsorption model of metal ions on the resorcinarene followed both of the pseudo second order of Ho's and Langmuir isotherm adsorption kinetics models with rate constant $(k)$ were $2.1 \times 10^{-2} \mathrm{~g} \cdot \mathrm{mg}^{-1} \cdot \mathrm{min}^{-1}$ for $\mathrm{Pb}(\mathrm{II})$ and $8.2 \times 10^{-3} \mathrm{~g} \cdot \mathrm{mg}^{-1} \cdot \mathrm{min}^{-1}$ for $\mathrm{Cd}(\mathrm{II})$. The adsorption equilibrium constant, $\mathrm{K}$, were $7.7 \times 10^{4} \mathrm{~L}^{\mathrm{mol}}{ }^{-1}$ for $\mathrm{Pb}$ (II) and $2.7 \times 10^{4} \mathrm{~L} . \mathrm{mol}^{-1}$ for $\mathrm{Cd}(\mathrm{III})$. The maximum sorption capacity of tetrakis-thiomethyl-C-4-methoxyphenyl calix[4]resorcinarene to $\mathrm{Pb}(\mathrm{II})$ and $\mathrm{Cd}(\mathrm{II})$ were 40.33 and $58.43 \mathrm{mg} \cdot \mathrm{g}^{-1}$ with adsorption energy of 27.88 and $25.27 \mathrm{~kJ}^{\mathrm{mol}}{ }^{-1}$ respectively.

\section{ACKNOWLEDGEMENT}

The authors gratefully acknowledge to the Directorate General of Higher Education, Republic of Indonesia, for financial support through the research grant of Hibah Bersaing 2011.

\section{REFERENCES}

1. Widianarko, B., and van Straalen, N.M., 2000, Ecotoxicol. Environ. Saf., 46, 1, 95-100.

2. Widianarko, B., Sulistyawati, I., and van Straalen, N.M., 2003, Indo. J. Environ. Chem. Toxicol., 1, 2, 1-10.

3. Hartono and Santosa, E.B., 2005, Enviro, 6, 2, 5863.

4. Broto and Syamsul, A.S., 2006, Jurnal IImu Tanah dan Lingkungan, 6, 2, 82-100.

5. Abidin, Z., and Sunardi, 2009, Indo. J. Chem., 9, 3, 425-431.

6. William, P.L., and James, R.C., 2000, Principles of Toxicology, $2^{\text {nd }}$ ed., New York, John Wiley and Sons.

7. Goswami, S., and Ghosh, U.C., 2005, Water SA, 31, 4, 597-602

8. Barros, M.A.S.D., Zola, A.S., Arroyo, P.A., Agular, E.F., and Tavares, C.R.G., 2003, Braz. J. Chem. Eng., 20, 4, 413-421.

9. Widihati, I.A.G., 2009, Jurnal Kimia, 3, 1, 27-32.

10. Nuryono and Suyanta, 2004, Indo. J. Chem., 4, 2 , 125-131.

11. Santosa, S.J., Siswanta, D., Kurniawan, A., and Rahmanto, W.H., 2007, Surf. Sci., 601, 51555161.

12. Cahyaningrum, S.E., and Amaria, 2005, Indo. J. Chem, 5, 2, 130-134.

13. Buhani and Suharso, 2006, Indo. J. Chem., 6, 1, 43-46.

14. Supriyanto, G., Handajani, U.S., Istanti, and Abdillah, M.J., 2005, Jurnal Kimia Lingkungan, 7, 1, 19-23

15. Djunaidi, M.C., Retno, A.L., Pratama, J.W., Siswanta, D., and Jumina, 2007, Alchemy, 6, 1, 40-49.

16. Utomo, S.B. and Susilowati, E., 2007, Enviro, 9, 1, 21-27

17. Jumina, Sarjono, R.E., Paramita, B.W., Siswanta, D., Santosa, S.J., Anwar, C., Sastrohamidjojo, H., 
Ohto, K., and Oshima, T., 2007, J. Chin. Chem. Soc., 54, 5, 1167-1178.

18. Utomo, S.B., Jumina, and Wahyuningsih, T.D., 2009, Indo. J. Chem., 9, 3, 437-444.

19. Arora, V., Chawla, H.M., and Singh, S.P., 2007, Arkivoc, 2, 172-200.

20. Puddephatt, R.J., 2006, Can. J. Chem., 84, 11, 1505-1514.

21. Fox, O.D., Cookson, J., Wilkinson, E.J.S., Drew, M.G.B.; MacLean, E.J., Teat, S.J., and Beer, P.D., 2006, J. Am. Chem. Soc., 128, 21, 6990-7002.

22. Moore, S.S., Tarnowski, T.L., Newcomb, M., and Cram, D.J., 1977, J. Am. Chem. Soc., 99, 19, 63986405.

23. Zhao, J., Bolte, M., Dordea, C., Gruner, B., and Bohmer, V., 2009, J. Synth. Org. Chem. Jpn., 23, 4063-4067.

24. Kalenius, E., Kekalainen, T., Neitola, R., Beyeh, K., Rissanen, K., and Vainiotalo, P., 2008, Chem. Eur. J., 14, 17, 5220-5228.
25. Boas, U., and Heegaard, P.M.H., 2004, Chem. Soc. Rev., 33, 1, 43-63.

26. Ho, Y.S., 2004, Scientometrics, 59, 1, 171-177.

27. Ho, Y.S., and Mckay, G., 2000, Water Res., 34, 3, 735-742.

28. Utomo, S.B., Jumina, Siswanta, D., Mustofa, and Kumar, N., 2011, Indo. J. Chem., 11, 1, 1-8.

29. Haiduc, I., and Edelmann, F.T., 1999, Supramolecular Organometalic Chemistry, Wiley$\mathrm{VCH}$, New York.

30. Nandi, B.K., Goswami, A., and Purkait, M.K., 2009, Appl. Clay Sci., 42, 3-4, 583-590.

31. Umaningrum, D., Santoso, U.T., Nurmasari, R., and Yunus, R., 2010, Indo. J. Chem., 10, 1, 80-87.

32. Ayu, Y.P., 2006, Study of The Adsorption of Lead (II), Copper (II), and Chromium (III) Metals Ion on C-Methylcalix[4]resorcinarene, Undergraduate Thesis, Universitas Gadjah Mada, Yogyakarta

33. Jumina, Sarjono, E.S., Matsyeh, S., and Kumar, N., 2001, BMIPA, 11, 3, 35-51. 